\title{
Processes of Urban Economic Development in China-A Case Study of Beijing
}

\author{
Irina A. Rodionova \\ Faculty of Economy \\ Peoples’ Friendship University of Russia (RUDN \\ University) \\ Moscow, Russian Federation \\ rodionova_ia@rudn.university
}

\author{
Natalia S. Sakharchuk \\ Institute of World Economy and Business \\ Peoples’ Friendship University of Russia (RUDN \\ University) \\ Moscow, Russian Federation \\ sakharchuk_ns@rudn.university
}

\begin{abstract}
Beijing is the capital of China and the very large economic center of the country. This has a significant impact on the modern development of the urban economy. The development of an urban economy is a complex comprehensive systematic task. An effective solution to the problems is of great importance for the economic development of both the capital region and the country as a whole. Analysis has shown changes in the ratio of the structure of the economic sectors and in the employment structure in favor of the tertiary sector of the urban economy. There have been changes in the ratio of numbers of employees in governmental and non-governmental sectors in Beijing. Beijing is still the center of attraction for labor resources. The main reason is the search for the most favorable economic conditions (employment in the labor market, higher wages, opportunities to master a new profession, to improve skills, etc.)
\end{abstract}

Keywords - China, Beijing, urban economy, employment, the structure of urban economy, sectors of economy

\section{INTRODUCTION}

The study of the features of economic development in China's largest cities is an urgent issue as in recent decades profound changes in the world economy have occurred in the context of globalization and with the direct participation of the PRC. Nearly half of the population inhabits cities and towns; this is where the main production potential of the state is located.

At present China ranks first in the world in terms of GDP at purchasing power parity (21.27 trillion US dollars, ahead of the United States (18.56 trillion US dollars) in 2016) and is among the world leaders in the aggregate macroeconomic indicators [1] China is the world leader in the production of many industries. This country has a number of urban centers, with the potential to compete with many of the global cities of the world.

China's major urban centers function as a segment of the network of global cities in the world. The purpose of the study is to present an integrated concept of the features of economic development in China's largest cities and of the employment structure in sectors of the urban economy (using Beijing as an example).

Scientific and theoretical grounds for the study were papers on global cities by leading Russian and foreign researchers. The data and statistical basis of the study includes: databases of international organizations (UN, IMF, World

The publication was financially supported by the Ministry of Education and Science of the Russian Federation (the Agreement number 02.a03.0008).
Bank); reports of analytical and consulting agencies on issues of urban development (Global Metro Monitor, Global Urban Competitiveness Report, Global Power Cities Index, etc.); statistical yearbooks, collections of works and reports on the development of urban economies issued by the State Statistical Bureau of China; the periodical press materials available on the Internet.

In September 2015 in New York a plan of action "Transforming Our World: The Agenda for Sustainable Development for the Period up to 2030" [2] was adopted at the 70th Session of the UN General Assembly. The document highlighted 17 global targets for future international cooperation (the 11th target was Sustainable Cities and Towns). In October 2016 in Quito, Ecuador, a new Agenda for urban development was adopted at the UN Conference on Housing and Sustainable Urban Development (Habitat III) [3]. In the fall of 2016 the Global Report of UNESCO "Culture: Urban Future" (on the role of culture in sustainable urban development) was published [4].

\section{CHINA's POSITION IN THE GLOBAL ECONOMY}

A. The positions of China's largest cities in the ranking of global cities of the world

At the turn of the 1980s and 1990s a theory of global cities was formed in academic literature. A number of foreign researchers (J. Friedman, S. Sassen, et al.) expressed ideas about the specifics of development of the greatest cities in the world in terms of globalization. The cities are called global precisely because of the growth of their importance in global economy.

The amount of scientific and applied research in the field of global cities continues to grow. Currently, rankings options of global cities have been presented on a regular basis by such major international structures as The Economist (Economist Intelligence Unit), A.T. Kearney, The Mori Memorial Foundation Institute for Urban Strategies (MMF), PWC, Knight Frank and others.

It is important to note that the large cities of China according to a whole range of criteria are comparable to the largest cities in the world and some of them have been 
classified as global (Hong Kong, Beijing, Shanghai, Guangzhou, Shenzhen, etc.) (Table. 1).

TABLE I. POSITIONS OF CHINESE TOWNS IN COMPREHENSIVE RANKINGS

\begin{tabular}{|c|c|c|}
\hline Name of ranking & $\begin{array}{c}\text { Towns } \\
\text { total }\end{array}$ & Chinese towns (rank) \\
\hline $\begin{array}{llr}\text { Global Power } & \text { Cities } \\
\text { Index, 2016 } & \\
\end{array}$ & 42 & $\begin{array}{l}\text { Hong Kong (7), Shanghai (12), } \\
\text { Beijing (17) }\end{array}$ \\
\hline $\begin{array}{l}\text { Global Power City Index, } \\
2013\end{array}$ & 40 & $\begin{array}{l}\text { Hong Kong (11), Shanghai (12), } \\
\text { Beijing (14) }\end{array}$ \\
\hline $\begin{array}{lcc}\text { A.T. } & \text { Kearney } & \text { Global } \\
\text { Cities Index } 2016 & \\
\end{array}$ & 125 & $\begin{array}{l}\text { Hong Kong (5), Beijing (9), } \\
\text { Shanghai (20), Guangzhou (71) }\end{array}$ \\
\hline $\begin{array}{l}\text { The } 2025 \text { Global City } \\
\text { Competitiveness Ranking } \\
\text { (forecast: The Economist } \\
\text { Intelligence Unit, 2012) }\end{array}$ & 120 & $\begin{array}{l}\text { Hong Kong (4), Shanghai (38), } \\
\text { Beijing (49), Shenzhen (69), } \\
\text { Tianjin (81), Qingdao (82), Dalian } \\
\text { and Suzhou (83), Chengdu (86), } \\
\text { Guangzhou (89) }\end{array}$ \\
\hline $\begin{array}{l}\text { Cities of Opportunities, } \\
2012\end{array}$ & 27 & $\begin{array}{l}\text { Hong Kong (8), Beijing (17), } \\
\text { Shanghai (19) }\end{array}$ \\
\hline $\begin{array}{ll}\text { Global } & \text { Urban } \\
\text { Competitiveness } 2012\end{array}$ & 99 & $\begin{array}{l}\text { Hong Kong (19), Shanghai (36), } \\
\text { Beijing (55) }\end{array}$ \\
\hline $\begin{array}{l}\text { Global Cities Index and } \\
\text { Emerging Cities Outlook, } \\
2012\end{array}$ & 65 & $\begin{array}{l}\text { Hong Kong (5), Beijing (14), } \\
\text { Shanghai (21), Guangzhou (60), } \\
\text { Shenzhen (65), Chongqing (66) }\end{array}$ \\
\hline $\begin{array}{l}\text { Global } \\
\text { Competitiveness Index, } \\
2012 \text { (The Economist } \\
\text { Intelligence Unit) }\end{array}$ & 120 & $\begin{array}{l}\text { Hong Kong (4-5), Beijing (39), } \\
\text { Shanghai (37), Shenzhen (52), } \\
\text { Guangzhou (64), Tianjin (75), } \\
\text { Dalian (82), Chengdu (83), } \\
\text { Suzhou (84), Chongqing (87), } \\
\text { Qingdao (91), Hangzhou (93) }\end{array}$ \\
\hline $\begin{array}{lr}\text { Global } & \text { Urban } \\
\text { Competitiveness } & \text { Report, } \\
2011 & \end{array}$ & 500 & $\begin{array}{l}\text { Hong Kong (10), Shanghai (37), } \\
\text { Beijing (56), Shenzhen ( }(71) \text {, } \\
\text { Macau (93), Guangzhou (120), } \\
\text { Tianjin (165), Dongguan (195) in } \\
\text { the first } 200 \text { in the ranking }\end{array}$ \\
\hline Global Cities Index, 2011 & 40 & $\begin{array}{l}\text { Beijing (8), Hong Kong (17), } \\
\text { Shanghai (18) }\end{array}$ \\
\hline $\begin{array}{lcc}\text { A.T. } & \text { Kearney } & \text { Global } \\
\text { Cities } & \text { Index } 2008 & \\
\end{array}$ & 59 & $\begin{array}{l}\text { Hong Kong (5), Beijing (12), } \\
\text { Shanghai (20), Guangzhou (52) }\end{array}$ \\
\hline
\end{tabular}

Source: Chubarov I.G. The geographical features of the formation of global cities in the PRC [5]; Global Urban Competitiveness 2012 [6]; Kearney A.T. Global Cities Report 2016 [7]; Global Power Cities Index 2016 [8]; The Economist Intelligence Unit 2012 (The 2025 Global City Competitiveness Ranking) [9].

The role of China's largest cities has been gaining strength rapidly in the world economy that is determined by a large set of both domestic and external factors. The total gross regional product (GRP) in three cities of China (Hong Kong, Shanghai and Beijing) has already exceeded the total GRP of major global cities in Europe (London and Paris) [6].

Many of China's largest firms are now among the 500 largest corporations in the world (103, second place behind the United States - 134, 2016). At the same time in the number of headquarters of the 500 largest TNCs (Fortune Global 500), Beijing, the capital of China, as of 2016 has already surpassed all the world's major cities (57 headquarters), leaving behind (the 2nd place) Tokyo, the capital of Japan (38 headquarters), followed by Paris, New York and London (17 headquarters). In addition, in Shanghai 10 multinationals from the Fortune Global 500 have already placed their headquarters (and in Seoul too) [10].

Chinese cities are part of the global urban network. They are dynamically developing. Moreover, China's integration into the world economy has allowed a number of Chinese cities to become global centers.

\section{B. Specifics of the structure development and formation in the modern economy of Beijing}

The role of cities in the economy is essential as the majority of financial and commodity markets are located in urban areas. In order to identify the economic role of a city the functioning of its spatial structures and the impact of these structures at urban, national and international levels should be examined. The city has its own special role in the areas of production, consumption and management. The concept of "functions of the city" is commonly used as a spatial economic analytical tool. In large cities with many enterprises offering a variety of functions, it is difficult to single out any specific leading industry. The actual operation of enterprises requires multifunctionality.

In our case, we study Beijing, the capital of China, and it, of course, is a multifunctional city. In addition, it is the capital of the state. Therefore, management functions are still of high importance here. Besides, Beijing functions as a redistribution hub in regard to economic information and other data. We shall consider further changes in the structure of Beijing's economy.

The development of Beijing is greatly enabled by such factors as available labor resources (including qualified staff), political stability in the country, efficient and flexible bureaucratic institutions, the strengthening of China's position in the global economy (including the country's integration into international economic processes, with headquarters of the largest TNCs present in the city).

The Development and Life Index allows a comprehensive monitoring of the development of administrative units in the country. The index is based on the method of calculating the index of human potential and a number of other indices. Beijing is placed first in ranking (with a very large margin of less-developed regions of China) [11].

Beijing is still the center of social life in China. Within it are all the most important national-level government departments. Beijing is the main recipient of investments in fixed assets (over 80\%). The location in the city of all the country's leading educational and scientific institutions and social and cultural organizations is also closely associated with the status of the capital.

One of the advantages in Beijing is the available "soft power" and the developed production services. Accordingly, Beijing should strive to occupy the position of a financial center, a center of innovation, and an administrative center [12].

The structure of the capital's economy in comparison to other Chinese global centers has pronounced "post-industrial” features as a result of rapid de-industrialization and for environmental reasons too. The volume of Beijing's GRP is growing. The share of the tertiary sector in Beijing's urban GRP is increasing. The volume of production in the primary and secondary sectors in value terms has increased twice since 2015, and in the service sector - three times (Table 2). 
TABLE II. GRP STRUCTURE OF BEIJING, 2005-2014

\begin{tabular}{|c|c|c|c|c|c|c|c|c|c|}
\hline & \multicolumn{2}{|c|}{$\mathbf{2 0 0 5}$} & \multicolumn{2}{c|}{$\mathbf{2 0 1 0}$} & \multicolumn{2}{c|}{$\mathbf{2 0 1 3}$} & \multicolumn{2}{c|}{$\mathbf{2 0 1 4}$} \\
\hline & $\begin{array}{c}\text { (million } \\
\text { yuan) }\end{array}$ & $\%$ & $\begin{array}{c}\text { (million } \\
\text { yuan) }\end{array}$ & $\%$ & $\begin{array}{c}\text { (million } \\
\text { yuan) }\end{array}$ & $\%$ & $\begin{array}{c}\text { (million } \\
\text { yuan) }\end{array}$ & $\%$ \\
\hline $\begin{array}{c}\text { Beijing } \\
\text { GRP }\end{array}$ & $6,969.52$ & 100.0 & $14,113.58$ & 100.0 & $19,800.81$ & 100.0 & $21,330.83$ & 100.0 \\
\hline \multicolumn{7}{|c|}{ Economy sectors } \\
\hline Primary & 88.68 & 1.27 & 124.36 & 0.88 & 159.64 & 0.81 & 158.99 & 0.75 \\
\hline Secondary & $2,026.51$ & 29.08 & $3,388.38$ & 24.01 & $4,292.56$ & 21.68 & $4,544.80$ & 21.31 \\
\hline Tertiary & $4,854.33$ & 69.65 & $10,600.84$ & 75.11 & $15,348.61$ & 77.52 & $16,627.04$ & 77.95 \\
\hline
\end{tabular}

Source: compiled by the author. Calculated according to the Research Database. Official Statistics of the PRC.

When describing the structure of the city's GRP we can definitively say that it has been mainly created by the service sector, however, the role of the industrial sector is significant enough too. This is a multifunctional center presenting all sectors of the economy, city forming and city maintaining.

The territorial and social mobility of the population, the development of new business areas, increasing the efficiency of production and consumption of material goods are all dependent on the extent of the development of the service sector. The development of various sectors of the economy of Beijing foresees changes in the number of people employed in them.

\section{The dynamics of the employment structure in economy sectors of Beijing}

The availability and quality of labor resources is of great importance for the economy of any country. China is characterized by contradictions between the population growth and overall poorly qualified labor force, and between the pace of economic development in different regions of China. The unemployment rate in large cities is much lower than in the overall country (and especially in less developed provinces in China), which defines significant internal migration flows. There is also a big difference between urban and rural areas in the educational attainment of labor resources [13].

It may be noted that there is a stable structure of employment in Beijing. The proportion of employed people in the secondary sector industries is low, while the share of employment in the tertiary sector is quite high, with the share of this sector growing (Table 3).

There have been alterations in social and labor relations. Before the transition, the state acted as an employer. Now, representatives of different forms of ownership may perform this role. As a result of such changes the ratio of people employed in the state and non-state sectors of the economy has transformed in Beijing (Table 4).

Although the share of employment in state-owned enterprises in Beijing dropped by 2014 (47.7\%), during the period analyzed there was an increase in the number of employees in public enterprises (an increase from 5702.6 to 7558.6 thousand people). The development of the non-state (private and individual) sector of the economy is a positive process.
TABLE III. THE MAIN PARAMETERS OF THE EMPLOYMENT STRUCTURE IN THE ECONOMY OF BEIJING IN 2008-2014

\begin{tabular}{|c|c|c|c|c|c|c|}
\hline & \multicolumn{2}{|c|}{$\mathbf{2 0 0 8}$} & \multicolumn{2}{c|}{$\mathbf{2 0 1 1}$} & \multicolumn{2}{c|}{$\mathbf{2 0 1 4}$} \\
\cline { 2 - 7 } & $\begin{array}{c}\text { Thousands } \\
\text { of people }\end{array}$ & $\%$ & $\begin{array}{c}\text { Thousands } \\
\text { of people }\end{array}$ & $\%$ & $\begin{array}{c}\text { Thousands } \\
\text { of people }\end{array}$ & $\%$ \\
\hline $\begin{array}{c}\text { Primary } \\
\text { sector }\end{array}$ & 71.5 & 1.25 & 90.8 & 1.32 & 93.4 & 1.24 \\
\hline $\begin{array}{c}\text { Secondar } \\
\text { y sector }\end{array}$ & 963.1 & 16.89 & $1,077.7$ & 15.71 & $1,000.3$ & 13.23 \\
\hline $\begin{array}{c}\text { Tertiary } \\
\text { sector }\end{array}$ & 4,668 & 81.86 & $5,690.4$ & 82.96 & $6,464.7$ & 85.53 \\
\hline
\end{tabular}

TABLE IV. THE STRUCTURE OF EMPLOYMENT BY TYPES OF ENTERPRISES IN BEIJING (IN\%)

\begin{tabular}{|c|c|c|c|c|c|c|c|}
\hline & $\mathbf{2 0 0 8}$ & $\mathbf{2 0 0 9}$ & $\mathbf{2 0 1 0}$ & $\mathbf{2 0 1 1}$ & $\mathbf{2 0 1 2}$ & $\mathbf{2 0 1 3}$ & $\mathbf{2 0 1 4}$ \\
\hline State enterprises & $56.36 \%$ & $56.42 \%$ & $55.14 \%$ & $55.11 \%$ & $54.77 \%$ & $53.69 \%$ & $47.70 \%$ \\
\hline Private enterprises & $33.16 \%$ & $33.36 \%$ & $35.12 \%$ & $35.97 \%$ & $37.08 \%$ & $38.18 \%$ & $45.79 \%$ \\
\hline $\begin{array}{c}\text { Individual } \\
\text { enterprises }\end{array}$ & $10.48 \%$ & $10.22 \%$ & $9.73 \%$ & $8.92 \%$ & $8.15 \%$ & $8.13 \%$ & $6.50 \%$ \\
\hline
\end{tabular}

With the deepening of economic reforms, the channels of searching for work have become more diverse. A policy of reducing the number of employees in state enterprises is being implemented in order to enhance economic efficiency [14]. Incentives to create and develop non-state enterprises increase the demand for labor. Most non-state enterprises are small or medium-sized. They have multiple channels of employment, flexible means of employment and relatively low employment requirements. These characteristics are especially important when attracting labor.

Working conditions and guarantees provided at state and non-state enterprises and organizations are different. It is worth noting that the level of wages in the non-state sector is above the level of pay in the state sector. Throughout the country, the employment in the state sector is more stable, and the employees have paid vacations and guaranteed sick leave.

The structure of employment in the service sector is dominated by real estate, renting and business services (18\%, 2014), wholesale and retail trade (over 12\%), information transmission, computer services (over 10\%), followed by transport and communication, etc.

In Beijing, the share of services from GRP is growing (Table 2). The level of employment in the service sector amounted to $85.5 \%$ in 2014 (Table 4).

Already today, Beijing is the center of political power, finance, innovation, etc. Speaking about prospects of the economic center in an industrial society, we can mention the fact that Beijing is becoming the center of software development in China [12]. Being aware of the massive labor force and generally not too high levels of education of the population, we can say that experts working in the field of finance, IT-industry and science are the highest paid. But jobs are easier to find in large cities.

Beijing is a modern city, a concentrated center of finance, information technology, science, education, innovation culture, production and trade. 


\section{CONCLUSION}

The development of Beijing's economy is a complex comprehensive planning task. An effective solution to the problem is of great importance to enhance the economic development of the capital of the PRC. The impact of globalization is seen as a positive process for Beijing.

The ratio in the industrial structure of Beijing's economy benefits the tertiary sector. In modern conditions, the growth of the economically active population is determined by various factors of the population's life and labor conditions. As shown by numerous studies carried out in Beijing, the main reason for the growth of the economically active population is still searching for the most favorable economic conditions, such as: employment in the labor market, higher wages, opportunities to get a new profession, to improve skills, etc. That is why major cities act as centers for attracting labor resources, particularly Beijing that generates an expanding demand for labor.

\section{REFERENCES}

[1] The World Factbook. Central Intelligence Agency. USA. https://www.cia.gov/library/publications/resources/the-world-factbook/

[2] UNESCO and Sustainable Development Goals http://en.unesco.org/sdgs

[3] HABITAT III. UN Conferences on housing and sustainable urban development.

http://www.egorod.ru/Documents/meropr/2016_10_16_habitat/HIII\%20 Outcomes\%20Presentation.pdfb
[4] UNESCO Global Report on Culture for Sustainable Urban Development. -http://www.unesco.org/new/en/culture/themes/culture-anddevelopment/culture-for-sustainable-urban-development/

[5] Chubarov I.G. The geographical features of the formation of global cities in the PRC. Abstract of the thesis for a Candidate's Dissertation. Moscow, 2013, p. 10

[6] Global Urban Competitiveness 2012. http://www.gucp.org/cities/CountryCities/CityList_English?orderYear= 2012\&order

[7] Kearney A.T. Global Cities 2016. https://www.atkearney.com/documents/10192/8178456/Global+Cities+2 016.pdf/8139cd44-c760-4a93-ad7d-11c5d347451a

[8] Global Power Cities Index, 2016 (Institute for Urban Strategies. The Mori Memorial Foundation - MMF). - http://www.mori-mfoundation.or.jp/english/ius2/gpci2/

[9] The Economist Intelligence Unit, 2012 (The 2025 Global City Competitiveness Ranking). - http://gtmarket.ru/news/2013/06/10/5987

[10] Fortune Global 500. - http://fortune.com/global500/2016/

[11] Samburova Ye.N., Mironenko K.V. Regional imbalances in China's economic development in the post-reform period (19782015)//Metamorphosis in the spatial organization of the world economy at the beginning of the XXI century. Monograph. Ed. by Prof. I.A. Rodionova. Book of University. Moscow, 2016, pp. 79-85

[12] Zhang Xianzhi. Beijing as a key component of the Bohai Bay region's economy. Scientific journal Management Consulting. 2009, vol. 4, pp.126-134. - http://cyberleninka.ru/article/n/pekin-kak-klyuchevayasostavlyayuschaya-ekonomiki-regiona-bohayskogo-zaliva

[13] Lu Fupin. Statistical research of manpower in China. Abstract of the thesis for a Candidate's Dissertation. Moscow State University of Economics, Statistics and Informatics. Moscow, 2007

[14] Zhao Syantsze. Employment Problems in China. Population. 2003, vol. 1. pp. $107-119$ 